GLOBAL JOURNAL OF EDUCATIONAL RESEARCH VOL 14, 2015: 9-17

COPYRIGHTC BACHUDO SCIENCE CO. LTD PRINTED IN NIGERIA. ISSN 1596-6224

www.globaljournalseries.com; Info@globaljournalseries.com

\title{
CORRELATES OF DAY SCHOOLIADULT LEARNERS AND STUDENTS ACADEMIC PERFORMANCE: IMPLICATION FOR COUNSELLING IN NIGERIA
}

\section{LOVE JOSEPHASOR ANDPAULINA MBUA ANAKE}

(Received 9, May 2014; Revision Accepted 9, September 2014)

\begin{abstract}
The purpose of the study was to identify those challenges that hinder the day schools students/adult learners the opportunity to learn information, master new skills and improve old ones. The academic performance of day school secondary students' grades and adult learners in Nigeria were influenced by factors such as, socioeconomic status, the quality of the home environment, parental involvement, societal aspirations and the school factor continue to influence the course of school achievement. To this, the writer critically looked at the challenges before the school and society and discuss how the values and expectation of the government, school/home can programme its activities for the projection and effective teaching and learning conditions for academic growth. On this, possible counselling implications were made to help improve the academic performance of day secondary school students and adult learners in Nigeria.
\end{abstract}

\section{INTRODUCTION}

The school is a community of those who teach and those who are taught, especially for the education of children, usually housed in a building designed and equipped for the purpose of educating its members in that society. This could be a day school or boarding school. A day school is a school for those who live at home (Webster Dictionary, 1990). It is therefore designed in such a way that no provision is made to accommodate students with in the school environment. The organizational structure of a typical Nigerian day secondary school is makeup of the principal, vice principle administration/academic subject heads, subject teachers, senior prefects, body of prefects, students, and non-teaching staff, accountant, Clerks and security-men.

Historically in a non school setting, an adult/non-traditional student is someone who is pursuing an elementary, undergraduate or graduate degree, but who does not need the definition of a "traditional" college student. They are independent students, employed full time, a person with dependents, a person who as a result of death or divorce; is now single and wishes to complete a degree program; a committer student; or a veteran of the military who has returned to the civilian world after serving in the armed forces (Illinois State, 2012).

In Nigeria, the adult programme in distributive education is a service rendered to employees, supervisors, managers and proprietors, courses of study are organized in cooperation with consultation and advisory groups from several occupational areas. Instruction is usually undertaken by part-time instructors who come from business, education, government and the professions. A continuous regular programme of study may be established leading to diploma in adult distributive education (Denga \& Denga, 2013).

Duties are delegated to special groups of persons-teachers/instructors according to their area of specialization, Educational activities are

Asor Love Joseph, Department of Educational Foundations, Guidance and Counselling University of Calabar, Calabar

Anake Paulina Mbua, Educational Foundations Guidance and Counselling, University of Calabar, Calabar 
more carefully planned, organized and carried out within the school environment. Educating the students at all levels of schooling involves various methods of evaluation, assessment, examination and selections. The curriculum is organized into syllabus, scheme of work and time-table to show the specific times that subjects should be taught to various groups or classes. These schools are designed to transmit knowledge of the cultural heritage of the society (Asuquo, Owan, Inaja \&Okon, 2005).

Therefore, the school is a centralizing experience. It offers to students, opportunities to learn information, master new skill, and or improve old ones; to participate in sports, arts and other activities to explore vocational choices and to relate well with others. It widens intellectual and social horizons, some students, however, experience day school not as an opportunity but as one more hindrance on the road to adulthood (Papalia, Olds \& Feldman, 2004).

Based on records of academic performance of students in secondary school state same factors such as socioeconomic status, the quality of the home environment and parental involvement continue to influence the course of school achievement. In a longitudinal study of 174 disadvantaged children, these factors, as measured in first grade, closely predicted improvement or deterioration in academic performance by age 16 (Jimenson Egeland Teo, 1999). Other factors include peer influence, quality of schooling, and perhaps most important -students (and parents) belief in their ability to succeed.

Given the cognitive changes and student typical experience, the academic performance of the student, depends not ${ }^{*}$ only on the type of school (day school), but on the individual's developmental stage, cognitive strengths and learning style, the society's traditions, educational objectives and future needs. All these vary substantially from person, place and time (Berger, 2001).

Finally across all day secondary schools/adult learning centres in Nigeria, the area of concerned, the learners are faced with the problem of lack of interested teachers/resource persons, poor teaching materials and uncomfortable learning environment, lack of funding by government and less attention given to day school and adult learners educational programmes. As a result the learners' interest is in getting the certificates at all odds and earning a political position, salary and promotion at already working place. Hence their aim is not to acquire the knowledge, skills and comprehend the learned experiences; this adversely influences their interest and performance in teaching/learning situation.

\section{FACTORS THAT INFLUENCES LEARNERS ACADEMIC PERFORMANCE}

1. The student in the school setting and
adult learner in higher education
As the students ability to think hypothetically and abstractly starts to emerge, they begin to abandon simplistic, concrete thinking and to construct more imaginative, comprehensive and complex world views. They become interested in the opinions and judgment of others- adult as well as peers - from a variety of background. At the same time they are ready, even eager to question every idea, preferring their opinion to others. Some question why they must attend day school? These thought affect their academic performance in school. One challenge in higher education is to understand how older adults identify themselves, adult learners want mobility and connection with family, education, work and community. Therefore colleges and universities need to know how adults picture themselves in terms of work, learning and social connections. Hence, colleges and universities have created more programmes that help older adult train for new careers, participate in community service, and learn while in retirement. However many institutions are not following suit which stuns the vast opportunities for both higher education and society to act upon adult learners shifting identities (Lakin, 2009).

\section{Self-efficacy beliefs and academic motivation of day school students I adult learner.}

Bandura, Barbaranelli, Caprara \& Pastorelli (1996) Zimmermari (1992) stated that, students who are high in self efficacy-who believe that they can master academic material and regulate their own learning are more likely to try to achieve and more likely to succeed, than students who do not believe in their own abilities. 
Self regulated learners set changing goals and use appropriate strategies to achieve them. They try hard, persist in the face of difficulties, and seek help when necessary. While students who do not believe in the ability to succeed tends to be frustrated and depress feelings that makes success harder to attain, Therefore, the day school system arid parents who want their children to do well in school, must see that students have yearning experiences that build a belief in their ability to succeed several factors, including parental beliefs and practices, socioeconomic status and peer influence affect parents' power to strengthen children's achievement. Parents' belief in their ability to promote their children's academic growth affects their success in doing so.

While day students with parents who are economically secure and who have high aspirations for their children tend to have children with high academic goals and achievement.

Peer influence may explain the down ward trend in academic motivation and achievement. Research have reviewed that students whose peer group were high achievers showed less decline in achievement and enjoyment of school, while those who associated with low achievers showed greater declines. This was true for both boys and girls, across ethnic group. (Ryan, 2001).

Research suggests that learners in their 50 s and over report a negative reaction when being labeled as "senior or older" (Lakin, 2009). They resist this label because they feel they do not view themselves as part of the group. They prefer in their 50s they should be labelled "aging" as it conveys a journey opposed to and ending. Another label is the term "retirement" which is being retired or at least redefined. Research suggests "retirees are now considered "prime time, or "recareers", they are career shifting of volunteering opposed to "wasting away". Thus, the use of descriptive language to label adult aged 55 and over need to be re-examined to create new identities for this group as the paradigm shifts, to motivate them for positive learning activities.

\section{Use of time}

Academic motivation and efficacy beliefs may affect the way day school students use their time. Some seem too busy with extracurricular activities, household chores, and outside work that seems a wonder that they can also get good grades. Many can combine and do well while others who seem to have plenty of time do not do so well. In a four year longitudinal study of 1 , 010 randomly selected ninth-grades in the St Paul, Minnesota public school (Shanahan \& Flaherty, 2001) on students use of time in school, home, social activities and future plans. The result showed that, more than half of the students were consistently active in a number of areas; homework, other school activities time with friends, and watching movies, household chores and in some cases, paid work such as baby sitting and gardening. These young people tend to do well in school and have more ambitions, plans for future schooling, marriage, occupation and citizenship than those who were less marriage, occupation and citizenship than those who were less committed; whether or not they have outside employment after school.

\section{Socioeconomic status and family environment \\ This factor affects the day school child} positively or negatively. Children of poor uneducated parents are more likely to experience negative family and school atmospheres and stressful events Felner, Brand, Dubois, Adan, Mulhall \& Evans (1995). The neighborhood a family can afford generally determines the quality of schooling and opportunities for higher education, and the availability of such opportunities together with attitudes in the neighborhood peer group affect motivation. Still students with disadvantage families and neighborhoods do well in school and improve their condition in life. Parents who invest time and effort in their children and who have a strong network of community support build the family's social capital (Coleman, 1988).

\section{Parental involvement and parenting style \\ Parents can affect their children's} education by becoming involved in their children's schooling, acting as advocates for their children and impressing teachers with the seriousness of the family's educational goals Bandura, (1996). Thus students of day schools whose progress are monitored by parents fare 
best.

Parenting style also can make a difference. The autocratic parent strike a balance between making demands and being responsive. Their children receive praise and privileges for good grades; poor grades being encouraged to try harder and offer help. While the permissive parents seem not to care about grades, makes no rules about watching television, do not attend school functions, (PTA) and neither help nor check their children's homework.

Among same ethnic groups, parenting style may be less important than other factors that affect motivation and academic performance.

\section{School factor}

The effect of a school strongly influences students achievement. A good day school with an orderly, un-oppressive atmosphere, an active, energetic principal and teachers who take part in making decisions of high expectations for students, emphasize academic more than extracurricular activities and closely monitor students performance will encourage students' interest and better out come.

Also students are more satisfied with school if they are allowed to participate in making rules and feel supported from teachers and other students. Day school that tailor teaching to students abilities get better results than schools that try to teach all students in the same way or method. Research on Sternberg's triarchic theory of intelligence found that students who are high in practical or creative intelligence do better when taught in a way that allows them to capitalize on those strengths and compensate for their weakness (Sternberg, 1997). Indeed, a combination of teaching styles may be most effective for all students.

The school curriculum may have a special focus; such as ethnic studies. Teaching is flexible, innovative and personalized; therefore to overcome negative effects of day school, teachers should work together closely and get to know the students well. Accordingly, Wynne (2013) stresses that adult learners increase their effort when motivated by a need, an interest, or a desire to learn. They are also motivated by the relevance of the material to be addressed and learn better when material is related to their own needs and interests. Thus for learners to be fully engaged in learning their attention must be fully focused on the material presented.

Furthermore, educational and vocational aspirations are influenced by several factors, including students' and parents' self efficacy beliefs, societal values and aspiration. While part time "work seems to have both negative and positive effects on educational, social and occupational development of the students in a day school.

The manifestation of increasing indiscipline among staff and students in the educational system are numerous. They include disregard for school rules and regulations, disobedience to constituted authority; lateness, absenteeism, extortion/exploitation, bullying, sexual harassment, membership of secretsocieties(cultism), vandalism, examination malpractices, rudeness, smoking, drug abuse, stealing, etc. all sort of professional misconduct exist among teaching, non-teaching staff and students, which affect the students performance negatively, for example, cultism affect the students' academic work, security in and outside campuses, school discipline and students management have all been adversely affected. While examination malpractices had led to students dismissal or partial results release or had all their results withheld for one reason or the other (Nwagwu, 1997).

Similarly, supervision and inspection of schools are two critical input and strategies towards ensuring standards and quality in the day school system. The departments charged with the responsibilities have been inactive and ineffective, office-bound, immobile, and illequipped to perform creditably. When they venture out for inspection their assignment are been influenced by brown envelopes. Unproductive staff are shelved for want of courageous and committed leadership. Meanwhile, the education system continues to degenerate and appalling results stare us in the face. There is loss of confidence in the system and employers complain seriously. Parents with financial resources send their children abroad or into expensive private schools. Some of the best teachers seek greener pastures abroad, including small countries like Botswana, Ghana and Lesotho. 


\section{Societal values and aspiration}

Crisis of values, mindlessness and antiintellectualism in Nigeria have obviously affected and indeed greatly determined the crisis in day schools system. Wealth and power acquired through corruption and 419 activities are honoured. Societal ills of reaping without sowing, get rich quick syndrome, etc are values and attitude that have crept into the educational system and now hold it hostage. Also the malaise of mindlessness. Many do not care what happen in and to academic work of the students/adult learners and how it affects the society. While anti-intellectual sentiment of the less educated or intelligent students say schooling is not the ultimate, politics is the short cut to wealth. All these create a laissez-faire attitude to academic work and distraction which result to poor performance in school examination.

Furthermore, in a non school setting as peculiar to adult learners, they have established opinions, values and beliefs which have been built up over time and arrived at following experience of families, relationships, work, community, politics, etc. These views cannot be dismissed and must be respected. Adults learn best in a democratic participatory and collaborative environment. They need to be actively involved in determining how and what they will learn, and they need active, not passive learning experiences (Aneke, 2012).

\section{Characteristics of adult learners}

To all their aspirations, the society sees the adult learner as a late comer with so many problems to accommodate learning activities into their numerous schedules. Similarly, today's societal views on older adults and aging consist of worn-out images in high number. These views come in negative images, prejudice and stereotypes which all affect identity. Negative images and prejudices through a societal lens can be very damaging to one's identity. For instance, the current idea that retirement is equivalent to "finished living". While prejudices affect identity, where one is compelled to step down because of age. Likewise, the society stereotype the individual at 80 as too old to learn; which could lead to one becoming more socially isolated, forgetting the opportunities to stay engaged (Boulton-Lewis, 2010). THE BENEFITS

\section{OF DAY SCHOOL}

The following are the advantages of day school over boarding school.

1. It is less expensive for parents/guardian because boarding fee is not paid.

2. Low cost of transportation for students who live near the school.

3. It is less expensive and gives room for parent to monitor their children at home, and the type of peer groups their children associate themselves with.

4. Religiously the children adopt to their parents' mood of worship and try to be always around them-There is a level of parent/child good relationship, and knowing who your child is what he/she can do and what he cannot.

5. The children also learn from their parents how to perform activities at home like cooking, cleaning and caring for their siblings after school. This creates a sense of love and family closeness. They also help in framework, trade or work for part-time payment to assist the family financially.

6. Day school also gives the child the opportunity to learn the values and norms of the society in which he/she lives.

7. The students have the opportunity of attending extra mural classes to read and acquire knowledge and skill of subject taught at school.

8. They also engage in extra curricula activities like sporting activities, outside school.

9. The availability of educational material such as textbooks, computers, radio, television for learning activities after school are at advantage to the academic success of children from high socioeconomic status. This helps the students, from such homes to start learning right from home. These also lay solid foundation for children to learn how to speak good English from home before they ever go to school (Njama, 2006).

10. Day school creates good relationship between parents, teachers and student helping to break communication links and motivate students academically. 
The negative effect of day school

The following are the disadvantages associated with day school.

1. Distance from home to school creates opportunities for lateness, truancy, lying to parents and teachers, immoral behaviours and disrespect, (pre-marital sexual practices and unwanted pregnancy). The learners are not under close observation and monitoring.

2. Work after school hours. Other activities such as minimal jobs, hawking, household chore, part-time jobs for salaries takes the students time for learning. The student becomes more interested in fast money making than aiming at achieving academic values of long term aims/objectives.

3. Planning: In terms of planning, the government is seen to be ill-prepared to meet the needs of day schools in the provision of adequate human and material resources.

4. Lack of trained teachers: Some teachers in day secondary schools and adult participatory education are not prepared, lack the experience, knowledge, and skills for effective teaching and learning out come.

5. Inadequateanduncomfortable classrooms: Lack of classroom space to accommodate all the learners enrolled have became a problem that the society will live within the educational system of Nigeria.

6. Lack of materials for teaching and learning situations. Basic course books for teachers and pupils, and audio-visual aids are lacking in schools. Behold, most parents sent their children to school on the expectation that government, with his campaign on free education, would provide learning materials for their children.

7. Irregular payment of salaries, promotions and allowances had created serious handicap for effective teaching and learning in school. These affect the academic performance of students, as they cannot give out what they do not have.

8. Provision and maintenance of infrastructure. No

conducive environment for teaching and learning due to poor infrastructure- buildings are few and dilapidated, desk are in bad shapes and classrooms are nothing to write home about.

Environmental factor and academic stress

9. General environment: The area in which a child lives affects his learning. For example/some children live very far from school and in remote areas or slums. As a result some tend not to be interested in school activities, because they can no longer cope with academic stress or work. On the other hand, the courses of adult learners at all levels could range from ten to twenty hours in length. Frequently, courses are offered not only in the evening but also during slack times of the work day and could be conducted in stores with adequate training facilities. While management and mid-management courses could be offered at night in extended blocks of time, most common are two and half to three hours for five sessions.

10. Over population and under population: over population result in overcrowding poor ventilation, susceptibility to communicable diseases, resulting in poor attendance and performance; dropout of student etc. leading to poor students and teacher relationships. While under population increases the cost of education;because teachers, maintenance of school facilities etc. are costed into the students' fee (Njama,2006: 188-190).

11. Lack of provision for physical handicap students, such as sensory problems, as a result of over crowded classroom, poor ventilation and lighting affect their poor sight and learning becomes deficient.

12. Lack of effective counselling services pre-service or in-service counselling section for students and teachers. These services are necessary to prepare the students before time and to be aware of what is expected of them. Okafor (1987) where this is lacking the students live in the dark with no clear direction to 
achieve their academic objective.

13. Students are not well informed about what courses to offer before entering for final examination (poor subjects combination for career choice).Some teachers are very unsympathetic and unfriendly to students; thereby helping to kill the little interest learning or schooling. Thereby pushing the child to social ills like stealing, truancy, premarital sex, abortion, poor health and death.

14. Rigid class schedule which does not take into account students' time and convince. And also teacher's unsympathetic and unfriendly approach to students; which help in killing the little interest space for learning and schooling. Thereby pushing the child to social ills like stealing truancy, premarital sex, abortion, drug use/abuse and poor performance in class work.

15. Poor Teaching Methods. Some teachers give unclear and imprecise instructions to students.

\section{SUGGESTIONS}

Although one may argue that the reason for day students' academic performance cannot be attributed entirely to the school itself. It is pertinent to note that students, parents and society had great influence on the academic performance of secondary school students. The following are the suggestions made to improve the student's performance.

Adult learners should become actively involved in any learning process in which they are engaged. This instructional philosophy stems from personal involvement by the facilitators with research or practice related to self-directed adult learning research has show that learners when given the option and encouragement do well.

1. The instructors should creates an educational environment in which learning can occurs. And also utilizes question in same way to take the learner through a prepared and logical sequence of content acquisition.

2. An androgogist need to identify the significant differences between adult learners and learners under eighteen.
This will help the adult learners to be self-directed having a repertoire of experiences and being internally motivated to learn.

\section{COUNSELLING IMPLICATION}

1. The government and parents should provide conducive learning environment at school and home. The environment should be such that give the students the moral courage and prestige to remain in school during school hours and also study at home under conducive environment.Also employ learning strategies that build higher confidence in adult learners.

2. The school time table, retraining of staff and adequate teaching and learning materials should be provided for all (school and non environment). The school system should be well structured and organized for effective teaching and learning in such a way that the students are not overstressed for academic work.

3. Teachers, instructors, adult learners and students relationship is very important for academic excellence therefore teacher should be interested in their students, knowing when they are absent from class and why. They should also show concern for their students and recognized their individual differences of slow and fast learners - and be able to accommodate all in teaching and learning experiences for easy assessment and evaluation.

4. Also adult educators must prioritize student advising to provide guidance to help learners to be realistic about the demands of learning and provide time management and study suggestions.

5. Retraining of teachers should be organize at interval to improve teacher's knowledge and skills. Also counsellor should always seek to include the adult in the planning of educational efforts

6. The school's line of staff from principal to non teaching should always check the teaching and learning activities as well as their movement in school.

7. Similarly, the government should also 
make available effective human and material resources to all secondary school to achieve the national aim and objective of education in Nigeria. This will effect positive improvement on student's academic performance.

8. Trained counselors should be posted to all day secondary, schools and also given the free hand to performance their duties of helping the child/learner in needs to come out from his/her educational. Vocational and personal social problems by giving them guidance and counselling services at appropriate time. Counselling activities should be extended to non-traditional school environment for the benefit of the adult learner.

\section{SUMMARY}

It is important to note that the academic performance of students does not depend totally on the school he/she attends but on other factors, such as, lifestyle of the person, their culture of poverty, and poor environment, the analysis of these aspects led to the conclusion that students are bound to perform poorly due to certain negative self concept they have about themselves. Such students may think that they cannot cope with the demands of school or the gap between their life-style and school is far top much for them to adjust. On the hand teachers claim the non-seriousness on the part of students, while students blame poor performance on the teaching methods of the instructors and inadequate facilities for teaching and learning (Okafor, Okeem\&Mereni, 1987).

Similarly, behaviourist scientists agrees that a person's behaviour is very much influenced not only by the individual's personality traits but also by the way he sees the world around him Okafor, et al (1987).

Finally, it is generally accepted that the individual is a product of his physical and social environment, his physiological structure, his wants, goals and his past experiences, has great effect on his academic performance.

Therefore the academic performance of the students will depend greatly on the individual's willingness or readiness, or his motivational effort to achieve his set goals.

\section{CONCLUSION}

Many cases have been studied as the etiological starting point for investigating the phenomena of school failure or success. Most notable among these are: the role of the family, family adaptability and cohesion, parental expectations, social change and the media, the educational system, reform and polities, and other psychological aspects such as intellectual capacity, motivation, self-esteem and selfconcept Broc, (2000). Also different activities in which students participate, both inside and outside the school itself, are among the multiple situations or agents that adversely impact on students academic performance not necessarily the type of school one attends.

\section{REFERENCES}

Asuquo, P. N. Inaja A. E., David B. E andBassey, P. N., 2005. Historical foundations of Education in Nigeria $2^{\text {nd }}$ Edition. NIVS in conjunction with (IBEPS), Calabar, Nigeria.

Bandura, A., Barbaranelli, C., Caprara, S. V andPastorelli, C., 1996. Multifaceted impact of self- efficacy beliefs on academic functioning. Child Development 67, 1206-1222.

Berger, K. S., 2001. The developing Person, through the life span. $5^{\text {th }}$ ed. New York.

Boulton-Lewis, G. M., 2010. Education and learning for the elderly: Why, how, what. Educational Gerontology.

Broc, M.A., 2000. Self-concept, self-esteem and academic performance in $4^{\text {th }}$ year secondary students. Psychological implications for guidance 18, 119-146.

Coleman, J. S., 1988. Social capital in the creation human capital. American Journal of Sociology. 94(Suppl. 95), 95120.

Denga, D. I andDenga, H. N., 2013. Entrepreneurship education: Emerging trends and the human engineering paradigm. Calabar: Clear Lines 
Publications.

Felner, R. D., Brand, S., Dubois, D. L., Adan, A. M., Muhall, P. E and Evans, E. G., 1995. Socioeconomic disadvantage, proximal environmental experiences and socioemotional and academic adjustment in early adolescence: investigation of a mediated effect. Child development. 66, $744-792$.

http://www.rit.edu/academicaffairs/characteristics -adult-learners

Illinois State University.,2012. An equal opportunity/affirmative action university encouraging diversity. Identity Standards, Appropriate Use Policy.

Jimerson, S., Egeland, B andTeo, A., 1999. A longitudinal study of achievement trajectories factors associated with change. Journal Educational
Psychology, 9, (1): 116-126.

Lakin, M. B., 2009. Forging new identities: Older adult in higher education. Journal of Continuing Education and Lifelong Learning.

Njama, P. O., 2006. Sociology of Education. Calabar: Double Diamond publications.

Nwagwu, C. C., 1997. The environment of crisis in the Nigeria education system. Comparative education 33, (1):

Okafor, F. C.,Okeem, E. G andMereni J. I., 1987. Foundations of Adult Education. Anambra: Pacific Publishers Ltd.

Paplia, D. E., Olds, S. W and Feldman, R. D., 2004. Human development $\left(9^{\text {th }}\right.$ ed.). New York: McGraw-Hill Companies. 